\title{
Which CAMe First, IT or Productivity? The VIRTUOUS CYCLE OF INVESTMENT AND USE IN ENTERPRISE SYSTEMS
}

\author{
Sinan Aral \\ MIT Sloan School of Management \\ Room NE20-336, 3 Cambridge Center \\ Cambridge, MA 02142 \\ sinana@mit.edu
}

\author{
Erik Brynjolfsson \\ MIT Sloan School of Management \\ Room E53-313, 50 Memorial Drive \\ Cambridge, MA 02142 \\ erikb@mit.edu
}

\author{
D.J. Wu \\ Georgia Institute of Technology \\ 800 West Peachtree Street NW \\ Atlanta, Georgia 30308 \\ dj.wu@mgt.gatech.edu
}

\begin{abstract}
While it is now well established that IT intensive firms are more productive, a critical question remains: Does IT cause productivity or are productive firms simply willing to spend more on IT? We address this question by examining the productivity and performance effects of enterprise systems investments in a uniquely detailed and comprehensive data set of 623 large, public U.S. firms. The data represent all U.S. customers of a large vendor during 1998-2005 and include the vendor's three main enterprise system suites: Enterprise Resource Planning (ERP), Supply Chain Management (SCM), and Customer Relationship Management (CRM). A particular benefit of our data is that they distinguish the purchase of enterprise systems from their installation and use. Since enterprise systems often take years to implement, firm performance at the time of purchase often differs markedly from performance after the systems "go live." Specifically, in our ERP data, we find that purchase events are uncorrelated with performance while go-live events are positively correlated. This indicates that the use of ERP systems actually causes performance gains rather than strong performance driving the purchase of ERP.
\end{abstract}

In contrast, for SCM and CRM, we find that performance is correlated with both purchase and golive events. Because SCM and CRM are installed after ERP, these results imply that firms that experience performance gains from ERP go on to purchase SCM and CRM. Our results are robust against several alternative explanations and specifications and suggest that a causal relationship between ERP and performance triggers additional IT adoption in firms that derive value from their initial investment. These results provide an explanation of simultaneity in IT value research that fits with rational economic decision-making: Firms that successfully implement IT, react by investing in more IT. Our work suggests replacing "either-or" views of causality with a positive feedback loop conceptualization in which successful IT investments initiate a "virtuous cycle" of investment and gain. Our work also reveals other important estimation issues that can help researchers identify relationships between IT and business value.

Keywords: Business Value of Information Technology, Productivity, Simultaneity, Causality, Software Investment, Production Function, Enterprise Resource Planning, Supply Chain Management, Customer Relationship Management. 


\section{Introduction}

Perhaps the most critical question in information technology (IT) business value research is whether or not IT investments cause increases in firm productivity and performance. While IT may be correlated with increased performance, determining causality is essential to understanding whether IT pays off or whether investment in IT is simply a byproduct of success stemming from other root causes. ${ }^{1}$ A definitive answer to this question has defied purely econometric solutions, such as instrumental variables, because good instruments generally do not exist. Case studies, which outline how firms change and improve their performance in concert with IT investments, are useful but difficult to generalize; just as productivity proponents can cite IT success stories, skeptics can cite cases of reverse causality, in which IT investments are enabled by excess cash flow.

The ideal empirical solution to this puzzle would separate the estimation of the IT investment decision from the use of IT and observe these discrete events across time in the same firms. By empirically distinguishing investment from use, researchers could disentangle the complex relationship between IT and firm performance.

In this study, we take advantage of a uniquely detailed and comprehensive data set that meets these stringent criteria to address the causality question in IT business value research. We examine IT business value in the context of "enterprise systems" - company-wide suites of business software devoted to particular processes integrated across the value chain, namely, Enterprise Resource Planning (ERP), Supply Chain Management (SCM), and Customer Relationship Management (CRM). We collected enterprise systems adoption data on all U.S. customers from the sales database of one large enterprise systems vendor from 1998 to 2005 and tested the productivity and performance implications of purchasing and going-live with the vendor's three main suites of enterprise systems ERP, SCM, and CRM. The data contain distinct entries for purchase and go-live events, which enables us to disentangle estimates of 'investment' from those of 'use.' Thus, in contrast to earlier studies, the finer granularity of our data permits us to address the question of causality directly.

Our research has three primary goals: to (1) pursue independent estimations of purchase and go-live decisions to shed light on the casual direction of relationships between enterprise systems and performance; (2) provide up-todate, large sample statistical evidence of the productivity and performance implications of enterprise systems; and (3) explore the differential productivity and performance implications of IT adoption in processes inside and outside firm boundaries.

Our results provide empirical evidence of a causal relationship between enterprise systems adoption and firm performance. In our ERP data, we find that purchase events are uncorrelated with performance while go-live events are positively correlated. This implies that the use of ERP systems actually causes performance gains rather than strong performance leading to the purchase of ERP. In our examination of SCM and CRM systems, performance is correlated with both purchase and with go-live. These results imply that firms experiencing performance gains from ERP adoption go on to purchase SCM and CRM. Our results are robust to several alternative explanations and specifications and together suggest a causal relationship between ERP and performance, which in turn triggers additional IT adoption in firms that derive value from their initial investment. These results provide an explanation of simultaneity in IT value research that fits with rational economic theory: As firms successfully implement IT (and complementary intangible investments) and experience greater marginal benefits from IT investments, they react by investing in more IT. We suggest replacing "either-or" views of causality with a more specific "positive feedback loop' conceptualization in which successful IT investments initiate a "virtuous cycle" of additional investment and additional gain.

Interestingly, we also find that external SCM and CRM systems, which extend the reach of IT beyond firm boundaries, have a significantly greater impact on productivity and performance than do internal ERP systems and that since 1998, SCM and CRM explain some of the performance gains originally attributed to ERP. Although there are several possible explanations for this result, the evidence is strongest for a selection effect, whereby, on average, firms that succeed with ERP go on to adopt SCM and CRM. Finally, we show that the lagged benefits of ERP implementation cannot explain the strong relationship between SCM and CRM adoption and performance in time series analyses. Together, these results provide evidence of a causal relationship between enterprise systems and

${ }^{1}$ See Brynjolfsson \& Hitt (2000) for a review of the IT and productivity literature, and remaining research issues. 
firm performance and demonstrate the importance of estimating returns from process-enabling IT systems simultaneously.

\section{Theory \& Literature}

\section{Addressing Simultaneity Bias in Estimates of the Returns to IT}

One of the most vexing problems in estimating the productivity or performance impacts of IT is simultaneity bias errors introduced into estimations of variables simultaneously determined by the same forces (Griliches \& Mairesse 1995). If differences in firm performance are known to firms when they choose inputs, then simple estimation procedures can upwardly bias estimates of input coefficients (Olley \& Pakes 1996). For example, firms with windfall profits due to causes other than IT might choose to invest that profit in new IT capital. Consequently, IT would be positively correlated with performance in the data. Standard regression models may wrongly attribute part of that performance difference to the investment itself. In this way, simultaneity not only creates difficulties in determining the causal direction of relationships between factor inputs and output, it can create incorrect estimates of the relationships themselves.

Several possible sources of simultaneity exist in the relationship between IT and firm performance. If positive shocks to productivity or output occur during the observation period, they may simultaneously effect investments in IT and the productivity and performance of firms. Shocks could also be industry or firm specific. If firms undertake large technology implementations when demand for their products is high or when they expect to perform well, estimates of the impact of IT adoption on output may be biased upward creating indeterminacy in causal interpretations (Brynjolfsson \& Hitt 2003). The decision to adopt enterprise systems could be correlated with performance for several reasons. A windfall could trigger expenditures designed to take a firm 'to the next level.' Frequently, positive performance gains are used to make new technology investments that build competitive barriers. In addition, managers expecting an up tick in demand for their products may invest in ERP. Ramping up of production frequently requires coordinated production planning activities which are the primary function of ERP systems.

Several econometric techniques attempt to correct coefficient estimates and enable tractable causal interpretations. The classic approach involves collecting data on instrumental variables correlated with IT purchases but contemporaneously uncorrelated with performance. For example, researchers use data pertaining to client server architectures (Brynjolfsson \& Hitt 1996), age of capital stock (Gao \& Hitt 2004), and capital constraints (Brynjolfsson \& Hitt 2003) to address simultaneity. In the case of panel data, various formulations of lagged values of dependent variables (Arellano \& Bond 1991) have served as instruments. Finally, estimates of difference equations, simultaneous equations, or seemingly unrelated regressions have been used in conjunction with instrumental variable methods to improve parameter estimates (Brynjolfsson \& Hitt 1996).

These methods advance our ability to estimate the impact of IT on productivity and performance. However, a good instrument is hard to find. Acquiring reliable data on variables strongly correlated with IT but uncorrelated with performance is not easy. Any correlation with performance disrupts the ability to correct for simultaneity, and instruments only weakly correlated with IT make it difficult to estimate its true impact. Instruments based on lagged values of the dependent variable may be contaminated by serial correlation and typically have low power, creating wide confidence intervals that make it difficult to precisely estimate the impact of IT (Brynjolfsson \& Hitt 2003).

We follow a fundamentally different empirical estimation approach. Instead of employing instrumental variable techniques, we estimate IT purchases and IT use separately. By empirically separating the purchase of IT from golive events, we distinguish firms' decisions to invest in new technology from the impact of using that technology in their daily businesses. If firm performance is correlated with use but uncorrelated with purchase, we can reasonably assume that the relationship with performance is not driven (at least primarily) by the simultaneous determination of investment and performance. This type of analysis is not possible with aggregate measures of IT investment or single instance adoption data, which are too coarse to disentangle the investment decision from the use of the technology. Our approach is loosely based on the work of Olley and Pakes (1996), who conceive of an econometric procedure that explicitly models firms' investment decisions as a function of their productivity. In our case, we collect data on and estimate purchase events separately from IT use. 


\section{Measuring Discrete IT Adoption Events}

Most studies measure IT adoption as a single occurrence. However, adoption of large-scale enterprise systems typically spans several years and is punctuated by discrete observable events, including the decision to adopt an enterprise suite, the date of purchase, and the go-live date.

For example, according to our interviews at Scientific-Atlanta, a large global supplier of transmission networks for broadband access, and digital subscriber systems and service, management decided to purchase an ERP system in 1992 when a new CEO came on board, purchased the system in December 1994, started implementation in July 1995, and went live with phase one in April 1996 and with the fully integrated system in January 1997. The success of the ERP implementation led the company to implementations of SCM/CRM systems (e.g., supply chain procurement using reverse auctions) during 2003-05. Figure 1 illustrates a typical timeline for the adoption of ERP, SCM, and CRM and clearly depicts the time distinction for each discrete (sequential) adoption event within each suite. Whereas Figure 1 depicts the specific dates of Scientific-Atlanta's timeline, adoption times between suites may overlap.

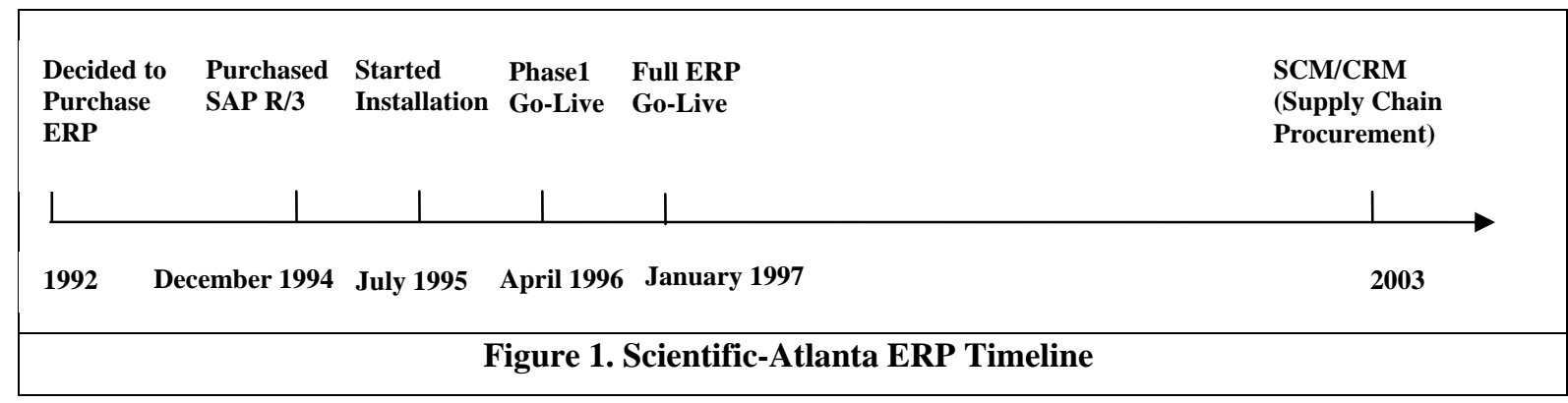

From our collected data, we can observe the exact dates of purchase and go-live events for 623 firms over eight years, which enables us to examine the performance effects of purchase and go-live events separately. If higher performance inspires IT adoption, performance should be associated with the decision to purchase a system, but if IT adoption drives performance, we expect to uncover no relationship between performance and purchase events and a positive relationship between performance and go-live events. ${ }^{2}$

\section{The Evolution of Enterprise Systems and Extensions Beyond the Firm}

Since the early 1970s, enterprise systems have evolved from Material Requirements Planning and Manufacturing Resource Planning systems popular in the 1980s to the more well-known ERP systems of the 1990s, which use a single data source that integrates enterprise functions such as sales and distribution, materials management, production planning, financial accounting, cost control, and human resource management.

In the last decade, ERP vendors began adding new suites such as SCM and CRM that can be fully integrated with ERP systems to expand the scope of enterprise software beyond the firm boundary to suppliers, partners, and customers. The ERP market grew $14 \%$ in 2004 and now accounts for approximately $\$ 25$ billion, while the implementation of systems dedicated to external processes has also grown to account for nearly $\$ 6$ billion (SCM) and $\$ 9$ billion (CRM). ${ }^{3}$ By 2002, more than 75\% of global Fortune 1000 firms had implemented SAP's ERP suite.

Although firms are relying more and more on enterprise systems to integrate processes, transactions, and data, we know relatively little about the productivity and performance effects of these process-enabling technologies. The few exceptions that exist in the literature examine either specific (rather than general purpose) technologies or isolated business processes (e.g., Barua et al. 1995; Ichniowski et al. 1997; Mukhopadhyay et al. 1997; McAfee

\footnotetext{
${ }^{2}$ Purchase events are lagged proxies for purchase decisions. Thus, the lack of a relationship between purchase and performance is a conservative refutation of the reverse causality argument.

${ }^{3}$ AMR “Market Analytix Report: Enterprise Resource Planning 2004-2009,” referenced in Network World, 06/15/05.
} 
2002). Recent work in the IT value literature advocates investigations of the performance implications of software investments (Melville et al. 2005), the differential returns to internal and external IT investments (Bharadwaj et al. 1999), and the impact of process-enabling IT. Furthermore, general purpose, process-enabling IT catalyzes significantly greater investments in organizational capital and, by some estimates, accounts for more than half of all IT-related investment (McAfee 2003). If IT matters for business performance, it should matter here.

\section{Enterprise Resource Planning}

Although enterprise systems constitute a significant and growing share of IT investments by most large and medium-sized firms, little empirical research examines the productivity and performance implications of these investments.

Previous evidence on ERP systems has come from qualitative case studies (e.g., Markus et al. 2000) or surveys of self-reported perceptual performance (e.g., Swanson and Wang 2003), but relatively few studies collect data from a large number of firms or use objective measures of productivity and performance. McAfee (2002) studies the impact of ERP adoption on lead time and on-time delivery in a single high-tech manufacturer and finds a "performance dip" immediately after adoption, followed by significant improvements after several months. Swanson and Wang (2003) survey 118 ERP adopters during the mid-to-late 1990s and identify business coordination (adoption know-why) and management understanding (implementation know-how) as critical success factors. In other words, successful ERP adopters appear to gain important knowledge advantages over less successful or failed ERP adopters for the next stage of enterprise IT innovations, such as SCM and CRM. Hendricks et al. (forthcoming) study the impact of ERP, SCM, and CRM adoption announcements and find SCM adopters experience positive returns in stock price performance, return-on-assets (ROA), and return-on-sales (ROS); no evidence of CRM returns in any measure; and some evidence of ERP returns for ROA and ROS but not for market value.

The study by Hitt et al. (2002), which was the largest published statistical analysis of the productivity and performance implications of ERP adoption, examines 350 publicly traded U.S. firms between 1986 and 1998 and finds that ERP adopters experience positive productivity, performance, and market value returns compared with non-adopters, though their data do not allow them to test whether ERP causes such performance gains. ${ }^{4}$

Most previous studies of ERP impact examine data prior to 1999, leaving a seven year gap in our understanding of the impacts of these nearly ubiquitous systems. Current estimates are critical because more recent ERP adoption is commonly accompanied by other types of process-enabling IT, such as SCM and CRM. If these other systems are correlated with ERP adoption and with better performance, the few estimates we have of the relationship between ERP and performance could be biased upward.

To understand how the market has changed since 1999, we analyzed qualitative case evidence in two stages prior to our econometric analysis. First, we reviewed more than 70 self-reported, multi-industry cases that documented clients' stories in implementing ERP, SCM, or CRM. Second, we conducted our own independent case studies of two high-tech companies that have implemented enterprise systems. ${ }^{5}$

Based on our qualitative case evidence and the prior literature on ERP adoption we hypothesize:

\section{H1: Firms that adopt ERP systems have greater productivity and performance than those that do} not.

\footnotetext{
${ }^{4}$ Hitt et al. (2002) had no purchase decision data and therefore could not separate IT purchases from implementation and use.

5 This process led to three broad findings: (1) intermediate performance enhancements drive the business value of enterprise software; (2) successful enterprise software implementations are accompanied by critical intangible investments and business process changes; and (3) successful implementers tailor adoption decisions, implementation plans, and process changes to their business strategies.
} 


\section{Supply Chain Management}

SCM systems not only support operational performance in terms of internal efficiencies and cost reduction (e.g. Cachon \& Fisher 2000), they enable firms to serve their customers in a timely and comprehensive manner. When a supply chain experiences glitches, firms experience reductions in their asset utilization, operational performance, and profitability (Hendricks \& Singhal 2005). Effective SCM can improve productivity and performance through two main complementary mechanisms established in the theoretical literature: market mediation and materials management (Fisher 1997).

Market mediation involves matching supply to demand, so effective market mediation requires accurate, timely information about the dynamics of supply and demand and incorporates IT-enabled processes, including collaborative planning and forecasting replenishment (CPFR), advanced supply chain planning, and logistics and distribution management. Information sharing and collaborative forecasting can mitigate the impact of demand variability on operations and reduce the upstream escalation of order variance known as the bullwhip effect (Lee et al. 1997). Improvements to demand forecasts enable firms to increase sales and order fulfillment rates and reduce inventory costs.

Materials management involves optimizing the movement of raw materials, work-in-process and finished goods inventories through the supply chain. Efficiencies in the materials management process minimize the costs of production, transportation, and inventory storage. Information sharing, CPFR, and supply chain optimization, can improve order quantity decisions, lower the time and costs of order processing, increase order frequencies, reduce lead times and batch sizes, reduce inventory levels, and increase order fulfillment (e.g., Cachon \& Fisher 2000). These operational improvements can reduce costs and lost sales, improve customer satisfaction and retention, and increase the performance of each individual firm in the supply chain. We therefore hypothesize:

\section{H2: Firms that adopt SCM systems have greater productivity and performance than those that do} not.

\section{Customer Relationship Management}

Competitive advantage and long-run business value depend more and more on a deep knowledge of and relationships with customers. Understanding the idiosyncrasies of heterogeneous customer preferences, valuations, and consumption behaviors, and determining customers' lifetime value can improve marketing decisions and returns on marketing expenditures (e.g., Hogan et al. 2002).

Although the impact of customer satisfaction, customer knowledge, and resultant marketing actions on firm performance have been examined (e.g., Andersen \& Sullivan 1993; Hogan et al. 2002), most studies typically focus on intermediate indicators, such as customer satisfaction, rather than bottom-line firm performance (Mithas \& Krishnan 2004; Mithas et al. 2005).

By enabling (1) effective sales force automation; (2) centralized customer data warehousing and data mining; and (3) decision support designed to inform marketing resource allocation decisions, promotion policies, and marketing campaigns to maximize customer satisfaction and retention, CRM can reduce costs by streamlining repetitive transactions and maximize data integrity by creating a central, firm-wide repository of customer information. Sales automation and centralized data enable data mining to identify dynamic changes in demand, cross-selling opportunities, and improvements in after-sales support to customers (Cohen et al. 2006). We therefore hypothesize:

H3: Firms that adopt CRM systems have greater productivity and performance than those that do not.

\section{Theoretical Implications of IT Adoption in Processes Beyond the Firm Boundary}

Despite research calls to examine the performance implications of IT adoption across firm boundaries (Bharadwaj et al. 1999; Melville et al. 2005), little large-sample empirical evidence exists. Both internal and external enterprise 
systems likely contribute to productivity and performance, but theoretically, external systems may have special implications for organizational structure, productivity, and performance.

The boundary of the firm has long been a theoretical demarcation across which investment incentives, coordination costs, and the distribution of information are theorized to change dramatically. These differences have economic implications for the structure of contracts, organizational decisions (such as making or buying intermediate inputs), and the existence of firms (Holmstrom \& Roberts 1998). Several theoretical arguments predict differential returns to IT within and across firm boundaries. There may be greater opportunities to reduce coordination costs between firms than within firms because of the additional transaction costs associated with economic activities outside the firm (Coase 1937; Clemons et al. 1993). In addition, because market procurement is more coordination intensive than internal production, the efficiency gains from automating or digitizing external transactions are potentially greater than those of IT-enabled process improvements within the firm. Finally, greater agency costs and potential opportunism, which could be addressed by improved monitoring and transparency provided by IT, may exist across firm boundaries (e.g., Jensen \& Meckling 1976). Working across firm boundaries requires greater management coordination and entails greater risks than working inside the firm. Firms that can overcome such barriers through the use of IT should earn greater returns, on average. Thus, prior theoretical and empirical work suggests:

H4: The performance impact of adopting enterprise systems outside firm boundaries (e.g., SCM, $C R M)$ is greater than that of adopting internal ERP systems.

\section{Empirical Methods}

\section{Data}

We collected detailed data on the enterprise systems purchase and go-live decisions of 2428 U.S. establishments from 1998 to 2005. The data include all U.S. sales of a major vendor's 150 software modules, collected directly from the vendor's sales database. As these data include distinct dates for purchase and go-live events, we measure both technology investment and use (Devaraj \& Kohli 2003). Based on interviews with the vendor's sales and technical staff, we grouped modules into clusters representing major packaged software offerings, including ERP, SCM, and CRM. The vendor's representatives validated our groupings, and we further verified them using a factor analysis of firms' adoption patterns. Our modules cluster cleanly, which suggests the groupings represent different software suites. The 2428 establishments represent 725 firms, 623 of which were publicly traded and whose matched performance data appears in the Compustat database. After removing private firms and those with missing data, we were left with an annual, balanced panel of 623 firms over eight years.

\begin{tabular}{lccccc}
\hline \multicolumn{7}{c}{ Table 1: Descriptive Statistics } \\
\hline Variable & Obs. & Mean & SD & Min & Max \\
\hline Sales (MM\$) & 4328 & 8466.18 & 20555.44 & 0 & 263989 \\
Employees (M) & 4155 & 28.87 & 67.23 & .002 & 905.766 \\
Capital (PPE Net) (MM\$) & 4313 & 3278.368 & 9269.58 & 0 & 111921 \\
Total Assets (MM\$) & 4334 & 12606.96 & 39568.93 & .07 & 798660 \\
Debt (MM\$) & 4330 & 1128.73 & 5712.48 & 0 & 93105 \\
Total Inventories (MM\$) & 4308 & 760.81 & 2308.09 & 0 & 58014 \\
COGS (MM\$) & 4328 & 5773.99 & 15503.58 & 0 & 263989 \\
Equity (MM\$) & 4334 & 3382.42 & 8699.79 & -22295 & 156293 \\
Pretax Income (MM\$) & 4327 & 385.325 & 1754.82 & -44574 & 25330 \\
Accts. Receivable (MM\$) & 4327 & 2651.62 & 13931.19 & 0 & 283824 \\
\hline MM = Millions, MM\$ = Millions of Dollars, M = Thousands, M\$= Thousands of Dollars \\
\hline
\end{tabular}


Table 2: Correlations Among Performance Variables

\begin{tabular}{|c|c|c|c|c|c|c|c|c|c|c|c|}
\hline & & 1 & 2 & 3 & 4 & 5 & 6 & 7 & 8 & 9 & 10 \\
\hline 1 & Sales & 1.00 & & & & & & & & & \\
\hline 2 & Employees & 0.72 & 1.00 & & & & & & & & \\
\hline 3 & Capital (PPE Net) & 0.80 & 0.56 & 1.00 & & & & & & & \\
\hline 4 & Total Assets & 0.73 & 0.52 & 0.66 & 1.00 & & & & & & \\
\hline 5 & Debt & 0.67 & 0.48 & 0.55 & 0.86 & 1.00 & & & & & \\
\hline 6 & Total Inventories & 0.68 & 0.55 & 0.48 & 0.65 & 0.59 & 1.00 & & & & \\
\hline 7 & COGS & 0.97 & 0.67 & 0.76 & 0.68 & 0.66 & 0.63 & 1.00 & & & \\
\hline 8 & Equity & 0.72 & 0.49 & 0.73 & 0.71 & 0.46 & 0.50 & 0.64 & 1.00 & & \\
\hline 9 & Pretax Income & 0.49 & 0.32 & 0.44 & 0.41 & 0.31 & 0.33 & 0.43 & 0.51 & 1.00 & \\
\hline 10 & Accts. Receivable & 0.57 & 0.40 & 0.40 & 0.82 & 0.84 & 0.69 & 0.55 & 0.41 & 0.29 & 1.00 \\
\hline
\end{tabular}

\section{Statistical Specifications}

Following the literature on IT, productivity, and business value (e.g., Brynjolfsson \& Hitt 1996, 2000), we employ two main empirical specifications and a third to check the robustness of our interpretations. We begin by closely replicating the specifications used by Hitt et al. (2002) (hereafter, HWZ) to ensure the comparability of our results with their work. We test the relationship between enterprise systems adoption and various measures of financial performance using the following general estimating equation: ${ }^{6}$

$\log ($ Performance Numerator $)=\alpha+\beta_{1} \log$ (Performance Denominator $)+\beta_{2}$ Adoption

$+\sum$ Year Controls $+\sum$ Industry Controls $+\varepsilon$.

In line with insights gained from our qualitative case studies, this estimation uses ratios that measure labor productivity, bottom-line profitability (ROA), and intermediate operational measures (e.g., inventory turnover, collection efficiency). ${ }^{7}$ We control for transitory shocks to performance by including a dummy variable for each year and industry controls for 10 industry groupings at the $1 \frac{1}{2}$ digit SIC level.

We then test the productivity effects of enterprise systems adoption using a traditional Cobb-Douglas specification, shown in its general form in equation 2 :

$$
\log (\mathrm{VA})=\alpha+\beta_{1} \log \mathrm{K}+\beta_{2} \log \mathrm{L}+\beta_{3} \text { Adoption }+\sum \text { Year Controls }+\sum \text { Industry Controls }+\varepsilon
$$

\footnotetext{
${ }^{6}$ Adoption variables are binary dummy variables tracking purchase, installation and go-live phases of adoption.

${ }^{7}$ We estimate the numerator of the performance ratio as the dependent variable and the denominator as a control variable: $\log (\mathrm{A})$

$=\alpha+\beta_{1} \log (\mathrm{B})+$ controls. This specification is based on the property that $\log (\mathrm{A} / \mathrm{B})=\log (\mathrm{A})-\log (\mathrm{B})$.
} 


\begin{tabular}{|c|c|c|c|}
\hline $\mathrm{Me}$ & ure (Ratio) & Definition & Internretation \\
\hline (1) & Labor Productivity & Sales/\# of Employees & $\begin{array}{l}\text { High ratio indicates higher labor } \\
\text { productivity }\end{array}$ \\
\hline (2) & Return on Assets & Pretax Income/Assets & $\begin{array}{l}\text { High ratio indicates efficient operation } \\
\text { of firm without regard to its financial } \\
\text { structure }\end{array}$ \\
\hline (3) & Inventory Turnover & $\begin{array}{l}\text { COGS/ } \\
\text { Inventory }\end{array}$ & $\begin{array}{l}\text { High ratio indicates more efficient } \\
\text { inventory management }\end{array}$ \\
\hline (4) & Return on Equity & Pretax Income/Equity & $\begin{array}{l}\text { High ratio indicates higher returns } \\
\text { accruing to the common shareholders }\end{array}$ \\
\hline (5) & Profit Margin & Pretax Income/Sales & $\begin{array}{l}\text { High ratio indicates high profit } \\
\text { generated by sales }\end{array}$ \\
\hline (6) & Asset Utilization & Sales/Assets & $\begin{array}{l}\text { High ratio indicates high level of sales } \\
\text { generated by total assets }\end{array}$ \\
\hline (7) & Collection Efficiency & Sales/Account Receivable & $\begin{array}{l}\text { High ratio indicates effective } \\
\text { management of customer payment }\end{array}$ \\
\hline (8) & Leverage & Debt/Equity & $\begin{array}{l}\text { The higher the ratio, the more } \\
\text { leveraged the firm }\end{array}$ \\
\hline
\end{tabular}

Finally, to verify our causal interpretations, we estimate a logistic regression of the probability of purchasing ERP, $\mathrm{SCM}$, and CRM as a function of performance: ${ }^{8}$

$$
\ln \left(\frac{P\left(Y_{i}=1\right)}{1-P\left(Y_{i}=1\right)}\right)=\alpha+\sum \beta X+\varepsilon
$$

\section{Results}

\section{Returns to ERP}

Our first task was to replicate the HWZ results, which examined productivity and performance effects of ERP adoption from 1986-1998. Our data differ from HWZ's in two ways other than their relative recency. First, to remain conservative in our estimates and acknowledge the widespread adoption of ERP systems in the last eight years, we do not pool our data with Compustat data on firms outside the sales database as a proxy for "nonadopters." Second, our data include more details about purchase and go-live decisions, whereas their study included only implementation start and end dates, not purchase, making causal analyses difficult. ${ }^{9}$ Although our data are more recent, more detailed, and do not include non-adopters, we can replicate HWZ's specifications by using implementation start and end dates in our data.

Table 4 displays HWZ's estimates of the impact of ERP adoption (defined as the "go-live" date) on performance in Row 1 (labeled 1ERP) and our updated results in Row 4 (labeled 2ERP). Although we use a completely new data set with no overlapping observations, our replication exercise produces remarkably similar results, inspiring confidence in both analyses. The specifications in which ERP adoption is statistically significant in HWZ's analyses are also significant in our new data set, and the point estimates are economically significant. For example, the estimate of .069 in column (1) indicates that ERP adopters experienced, on average, 6.9\% greater labor productivity. However,

\footnotetext{
${ }^{8} \beta \mathrm{X}$ represents performance.

${ }^{9}$ We also analyzed models including intermediate "installation" events which did not substantially change the results. We focus on purchase and go-live events as they best represent purchase decisions and IT use.
} 
we also find some significant improvements in the performance impacts of ERP in recent years compared with HWZ's findings. Estimates of the impact of ERP adoption on ROA, inventory turnover, return on equity, and profit margins are very similar, whereas asset utilization and collection efficiency show dramatic improvements in our data (columns $6 \&$ 7). The estimate of leverage (debt-to-equity ratio, column 8) also indicates a larger parameter estimate $(p<.05)$, and the estimate of labor productivity is smaller in magnitude though still highly significant. We find no measurable productivity returns to ERP adoption in Cobb-Douglas specifications (column 9), echoing the results of HWZ.

\begin{tabular}{|c|c|c|c|c|c|c|c|c|c|}
\hline Test & (1) & (2) & (3) & (4) & (5) & (6) & (7) & (8) & (9) \\
\hline & $\begin{array}{l}\text { Labor } \\
\text { Prod. }\end{array}$ & ROA & $\begin{array}{l}\text { Invent } \\
\text { Turn }\end{array}$ & ROE & $\begin{array}{l}\text { Profit } \\
\text { Mrgn. }\end{array}$ & $\begin{array}{l}\text { Asset } \\
\text { Util. }\end{array}$ & $\begin{array}{l}\text { Collection } \\
\text { Efficiency }\end{array}$ & Leverag. & $\begin{array}{l}\text { Output } \\
\text { (Prod.) }\end{array}$ \\
\hline 1ERP & $.163^{* * *}$ & -.073 & $.126^{* * *}$ & -.085 & -.036 & -.016 & .008 & .106 & -.017 \\
\hline $86-98$ & $(.048)$ & $(.072)$ & $(.061)$ & (.061) & $(.073)$ & $(.033)$ & $(.043)$ & $(.089)$ & $(.017)$ \\
\hline $\mathrm{R}^{2}$ & .91 & .82 & .86 & .88 & .82 & .96 & .92 & .77 & .98 \\
\hline Obs. & 4069 & 4069 & 4069 & 4069 & 4069 & 4069 & 4069 & 4069 & 4069 \\
\hline 2ERP & $.069 * *$ & -.043 & $.143^{* * *}$ & -.061 & -.072 & $.155^{* * *}$ & $.086^{* * *}$ & $.166^{* *}$ & -.002 \\
\hline 98-05 & $(.028)$ & $(.043)$ & $(.035)$ & $(.044)$ & $(.044)$ & $(.024)$ & $(.023)$ & $(.072)$ & $(.018)$ \\
\hline $\mathrm{R}^{2}$ & .87 & . 77 & .82 & .77 & .77 & .91 & .91 & .62 & .95 \\
\hline Obs. & 4135 & 3160 & 3593 & 3095 & 3160 & 4302 & 4251 & 3669 & 4117 \\
\hline
\end{tabular}

Our results demonstrate that ERP adoption strongly influences operational performance (inventory turnover, asset utilization, collection efficiency) and labor productivity but has a negligible impact on measures of financial return or profitability. These results motivate important questions about what has changed in the past decade. For example, what explains the strong positive impact of ERP adoption on collection efficiency and asset utilization in more recent data? It may be that ERP systems have improved over time. Organizational practices and business processes that deal with sales and customer payments also may have matured or been more tightly integrated into enterprise systems. We may also be noting the effects of new enterprise IT innovations correlated with ERP that contribute to firm performance. For example, if ERP adoption is correlated with the adoption of SCM and CRM and these technologies contribute to performance, omitting them could bias our estimates of the returns to ERP upward.

\section{Addressing Simultaneity Bias in the Returns to ERP}

If endogeneity exists in the relationship between ERP adoption and performance, simple estimates of a single binary adoption variable may be measured with error. However, separate estimates of purchase and go-live events can attribute variance to the purchase decision and the use of the technology separately.

If performance determines adoption, purchase events should return positive and significant coefficient estimates, but if adoption determines performance, performance should be positively associated with go-live events, not purchase events.

As the results in Table 5 clearly demonstrate, purchase events are uncorrelated with performance. Go-live events in contrast are strongly correlated with higher labor productivity, inventory turnover, asset utilization, and collection

\footnotetext{
${ }^{10}$ Table 4 combines results from separate regressions of returns to ERP reported in HWZ (Row 1) with our current study (Row 4). Although their coefficients are not shown, each regression includes control variables specified in equations 1 and 2 . Parameter estimates represent go-live events from both studies.
} 
efficiency. These estimates imply that simultaneity bias is not affecting our results and lend credibility to the argument that ERP adoption drives performance, rather than higher performance compelling firms to adopt ERP. ${ }^{11}$

\begin{tabular}{|c|c|c|c|c|c|c|c|c|}
\hline $\begin{array}{l}\text { Dependent } \\
\text { Variable }\end{array}$ & $\ln$ (Sales) & $\begin{array}{c}\ln (\text { Pretax } \\
\text { Income) }\end{array}$ & $\operatorname{Ln}(\mathrm{COGS})$ & $\begin{array}{c}\ln \text { (Pretax } \\
\text { Income) }\end{array}$ & $\begin{array}{c}\ln (\text { Pretax } \\
\text { Income })\end{array}$ & $\ln$ (Sales) & $\ln$ (Sales) & $\ln ($ Debt $)$ \\
\hline Column & (1) & (2) & (3) & (4) & (5) & (6) & (7) & (8) \\
\hline Interpretation & $\begin{array}{l}\text { Labor } \\
\text { Prod. }\end{array}$ & ROA & $\begin{array}{l}\text { Inventory } \\
\text { Turnover }\end{array}$ & ROE & $\begin{array}{c}\text { Profit } \\
\text { Margin }\end{array}$ & $\begin{array}{c}\text { Asset } \\
\text { Utilization }\end{array}$ & $\begin{array}{l}\text { Collection } \\
\text { Efficiency }\end{array}$ & Leverage \\
\hline $\begin{array}{l}\text { ERP: } \\
\text { Purchase }\end{array}$ & $\begin{array}{c}.009 \\
(.045)\end{array}$ & $\begin{array}{l}.004 \\
(.068)\end{array}$ & $\begin{array}{c}.040 \\
(.056)\end{array}$ & $\begin{array}{l}-.026 \\
(.073)\end{array}$ & $\begin{array}{c}.005 \\
(.068)\end{array}$ & $\begin{array}{c}.049 \\
(.041)\end{array}$ & $\begin{array}{l}.041 \\
(.029)\end{array}$ & $\begin{array}{c}.050 \\
(.105)\end{array}$ \\
\hline ERP: Go Live & $\begin{array}{l}.071^{* *} \\
(.030)\end{array}$ & $\begin{array}{l}-.044 \\
(.046)\end{array}$ & $\begin{array}{l}.152 * * * \\
(.039)\end{array}$ & $\begin{array}{l}-.068 \\
(.048)\end{array}$ & $\begin{array}{l}-.070 \\
(.047)\end{array}$ & $\begin{array}{c}.166^{* * * *} \\
(.027)\end{array}$ & $\begin{array}{c}.095^{* * * *} \\
(.025)\end{array}$ & $\begin{array}{l}.178 * * \\
(.077)\end{array}$ \\
\hline $\ln$ (Employees) & $\begin{array}{c}1.001 * * * \\
(.010)\end{array}$ & & & & & & & \\
\hline $\ln$ (Assets) & & $\begin{array}{c}.954 * * * \\
(.012)\end{array}$ & & & & $\begin{array}{c}.984 * * * \\
(.008)\end{array}$ & & \\
\hline $\ln$ (Inventory) & & & $\begin{array}{c}.905^{* * *} \\
(.010)\end{array}$ & & & & & \\
\hline $\ln$ (Equity) & & & & $\begin{array}{c}.989 * * * \\
(.015)\end{array}$ & & & & $\begin{array}{c}.964 * * * \\
(.021)\end{array}$ \\
\hline $\ln ($ Sales $)$ & & & & & $\begin{array}{c}.968^{* * *} \\
(.012)\end{array}$ & & & \\
\hline $\begin{array}{l}\ln \text { (Accounts } \\
\text { Rcv) }\end{array}$ & & & & & & & $\begin{array}{c}.900^{* * *} \\
(.008)\end{array}$ & \\
\hline Control & Industry & Industry & Industry & Industry & Industry & Industry & Industry & Industry \\
\hline Variables & Year & Year & Year & Year & Year & Year & Year & Year \\
\hline $\mathrm{R}^{2}$ & .87 & .77 & .82 & .77 & .77 & .91 & .91 & .62 \\
\hline Observations & 4135 & 3160 & 3593 & 3095 & 3160 & 4302 & 4251 & 3669 \\
\hline
\end{tabular}

\section{Returns to Extended Enterprise Systems: SCM \& CRM}

We first estimate the returns to SCM and CRM go-live events separately and find strong positive associations between SCM and CRM and labor productivity (SCM: $\beta=.352, p<.001$; CRM: $\beta=.341, p<.001$ ), inventory turnover (SCM: $\beta=.187, p<.001$; CRM: $\beta=.288, p<.001$ ), ROE (SCM: $\beta=.146, p<.10$; CRM: $\beta=.362, p<$ .10 ), and asset utilization (SCM: $\beta=.139, p<.001$; CRM: $\beta=.167, p<.05$ ), as well as a strong positive association between SCM and collection efficiency $(\beta=.178, p<.001) .{ }^{12}$ These results provide initial evidence of the greater impact of external systems on productivity and performance, though these specifications do not compare ERP, SCM, and CRM directly. If firms adopt these systems in concert, we must estimate them simultaneously to determine which systems truly drive performance and to control for SCM and CRM as possible omitted variables in ERP estimates. Table 6 presents the results of these analyses for financial performance metrics.

\footnotetext{
${ }^{11}$ Some firms that purchase ERP never implement or go-live. Our data highlight performance differences between firms that purchase ERP but never go live and those that see implementation through to use.

${ }^{12}$ Table omitted due to space constraints, but is available upon request.
} 


\begin{tabular}{|c|c|c|c|c|c|c|c|c|}
\hline \multicolumn{9}{|c|}{ Table 6: Returns to ERP, SCM, and CRM Evaluated Simultaneously ${ }^{13}$} \\
\hline $\begin{array}{l}\text { Dependent } \\
\text { Variable }\end{array}$ & $\ln$ (Sales) & $\begin{array}{l}\ln (\text { Pretax } \\
\text { Income) }\end{array}$ & $\operatorname{Ln}(\mathrm{COGS})$ & $\begin{array}{l}\ln (\text { Pretax } \\
\text { Income) }\end{array}$ & $\begin{array}{l}\ln (\text { Pretax } \\
\text { Income) }\end{array}$ & $\ln ($ Sales $)$ & $\ln ($ Sales $)$ & $\ln ($ Debt $)$ \\
\hline Column & $(1)$ & $(2)$ & (3) & $(4)$ & $(5)$ & (6) & (7) & (8) \\
\hline Interpretation & $\begin{array}{l}\text { Labor } \\
\text { Prod. }\end{array}$ & ROA & $\begin{array}{l}\text { Inventory } \\
\text { Turnover }\end{array}$ & ROE & $\begin{array}{c}\text { Profit } \\
\text { Margin }\end{array}$ & $\begin{array}{c}\text { Asset } \\
\text { Utilization }\end{array}$ & $\begin{array}{l}\text { Collection } \\
\text { Efficiency }\end{array}$ & Leverage \\
\hline ERP live & $\begin{array}{l}.055^{*} \\
(.029)\end{array}$ & $\begin{array}{c}-.097^{* *} \\
(.046)\end{array}$ & $\begin{array}{c}.100 * * \\
(.040)\end{array}$ & $\begin{array}{c}.138^{* *} \\
(.047)\end{array}$ & $\begin{array}{c}-.107^{* *} \\
(.048)\end{array}$ & $\begin{array}{c}.134 * * * \\
(.026)\end{array}$ & $\begin{array}{c}.036 \\
(.027)\end{array}$ & $\begin{array}{l}.119 \\
(.080)\end{array}$ \\
\hline SCM live & $\begin{array}{c}.373 * * * \\
(.040)\end{array}$ & $\begin{array}{l}.150 * * \\
(.066)\end{array}$ & $\begin{array}{l}.125^{* *} \\
(.045)\end{array}$ & $\begin{array}{l}.205^{* *} \\
(.068)\end{array}$ & $\begin{array}{l}.099 \\
(.067)\end{array}$ & $\begin{array}{l}.060 * * \\
(.027)\end{array}$ & $\begin{array}{c}.160 * * * \\
(.033)\end{array}$ & $\begin{array}{l}.145 \\
(.097)\end{array}$ \\
\hline CRM live & $\begin{array}{c}.219 \\
(.136) \\
\end{array}$ & $\begin{array}{l}.186 \\
(.167) \\
\end{array}$ & $\begin{array}{l}.218^{*} \\
(.121) \\
\end{array}$ & $\begin{array}{l}.314^{*} \\
(.186) \\
\end{array}$ & $\begin{array}{l}.128 \\
(.165) \\
\end{array}$ & $\begin{array}{l}.106^{*} \\
(.059) \\
\end{array}$ & $\begin{array}{l}-.042 \\
(.098) \\
\end{array}$ & $\begin{array}{l}-.095 \\
(.269) \\
\end{array}$ \\
\hline Control & Industry & Industry & Industry & Industry & Industry & Industry & Industry & Industry \\
\hline Variables & Year & Year & Year & Year & Year & Year & Year & Year \\
\hline $\mathrm{R}^{2}$ & .87 & .77 & .82 & .77 & .77 & .91 & .91 & .62 \\
\hline Observations & 4135 & 3160 & 3593 & 3095 & 3160 & 4302 & 4251 & 3669 \\
\hline
\end{tabular}

When all three suites of enterprise systems are estimated simultaneously, the positive impact of ERP on performance is explained to some degree by SCM and CRM. ${ }^{14}$ Although our parameter estimates of the returns to ERP are very similar to those in HWZ, when ERP is evaluated alone, some of the positive impact of ERP on performance is explained by SCM and CRM when we evaluate all three module suites together. In estimates of ERP alone, positive correlations exist with labor productivity, inventory turnover, asset utilization, and collection efficiency (Table 4). When all three variables are entered simultaneously, SCM and CRM are positively correlated with productivity and performance, while the returns to ERP are mitigated and, in the case of productivity, become negative (Table 5). ${ }^{15}$ When we control for the impact of SCM and CRM, the impacts of ERP adoption on operational performance are either reduced in magnitude and significance or, in the case of labor productivity, become slightly negative; the impacts of ERP on ROA, ROE, and profit margin remain negative but become significant; and estimates of the impact of ERP adoption on productivity behave similarly to the labor productivity estimate (Tables 6,7 ).

These results suggest our original estimates of ERP are measured with error and that the omission of SCM and CRM creates an upward bias in estimates of ERP alone. We consider four possible explanations for these results: omitted variable bias, delayed performance effects of ERP, a selection effect that separates successful ERP implementers from unsuccessful ones, and complementarities across systems of process-enabling IT. Regardless of the interpretation, our estimates demonstrate a bias associated with estimates of individual enterprise systems in isolation.

\footnotetext{
${ }^{13}$ We do not report control variable estimates in Tables $6,8,10,12$ or 13 because they are nearly identical to the coefficients in Table 5. Controls explain much of the variance in performance numerators specified in equation 1 resulting in high $\mathrm{R}^{2}$ values.

${ }^{14}$ We have a limited number of CRM observations. Though parameter estimates are large, confidence intervals remain wide, making statistically significant estimates difficult to observe.

${ }^{15} \mathrm{SCM}$ is highly significant; CRM is only marginally insignificant $(p<.11)$.
} 


\begin{tabular}{|c|c|c|}
\hline Dependent Variable & $\ln ($ Output) & $\ln$ (Output) \\
\hline Column & (1) & (2) \\
\hline $\ln$ (Capital) & $\begin{array}{c}.204^{* * *} * \\
(.009)\end{array}$ & $\begin{array}{c}.202 * * * \\
(.009)\end{array}$ \\
\hline $\ln$ (Labor) & $\begin{array}{c}.229 * * * \\
(.016)\end{array}$ & $\begin{array}{c}.232 * * * \\
(.016)\end{array}$ \\
\hline $\ln ($ Material) & $\begin{array}{c}.569 * * * \\
(.016)\end{array}$ & $\begin{array}{c}.566 * * * \\
(.016)\end{array}$ \\
\hline ERP live & $\begin{array}{l}-.002 \\
(.017)\end{array}$ & $\begin{array}{c}-.041 * * \\
(.018)\end{array}$ \\
\hline SCM live & & $\begin{array}{c}.120^{* * * *} \\
(.021)\end{array}$ \\
\hline CRM live & & $\begin{array}{c}.059 \\
(.037)\end{array}$ \\
\hline Control Variables & $\begin{array}{c}\text { Industry } \\
\text { Year }\end{array}$ & $\begin{array}{c}\text { Industry } \\
\text { Year }\end{array}$ \\
\hline $\mathrm{R}^{2}$ & .95 & .95 \\
\hline Observations & 4117 & 4117 \\
\hline
\end{tabular}

\section{Explanation 1: Omitted Variable Bias}

One interpretation of the upward bias in estimates of ERP in isolation is that ERP is a proxy for the positive performance impacts of the omitted variables (SCM and CRM), which may explain part of the performance benefits originally attributed to ERP. Although ERP's estimated effects are mitigated, it is unlikely ERP has no performance effect absent SCM and CRM. McAfee (2002) finds strong positive performance effects from ERP in the absence of SCM and CRM, and HWZ find positive ERP performance impacts during a period when SCM and CRM were almost nonexistent or at least not widespread enough to drive their results.

\section{Explanation 2: Delayed Performance Effects of ERP}

The positive performance impacts of SCM and CRM may reflect delayed performance effects of ERP systems adopted in previous years, an explanation consistent with evidence of the delayed performance effects of IT (Brynjolfsson \& Hitt 2003). The performance effects of ERP may be realized years after implementation (e.g., O'Leary 2000), in part because organizational changes and intangible investments in human capital and new business processes take time to implement. If the lagged effect of ERP is omitted from our estimation, we may incorrectly attribute the delayed performance impacts of ERP to SCM and CRM. To evaluate this alternative explanation, we employ a simple distributed lag specification including three years of lagged ERP adoption. ${ }^{16}$

\footnotetext{
${ }^{16}$ We use three years of lagged ERP go-live events to conform to estimates of the lag in ERP benefits (e.g., Hendricks et al. forthcoming). Including fewer or more lags does not significantly change our results.
} 


\section{Table 8: Performance Returns to SCM and CRM and Lagged Estimates of ERP}

\begin{tabular}{|c|c|c|c|c|c|c|c|c|}
\hline $\begin{array}{l}\text { Dependent } \\
\text { Variable }\end{array}$ & $\ln ($ Sales $)$ & $\begin{array}{c}\ln (\text { Pretax } \\
\text { Income }) \\
\end{array}$ & Ln(COGS) & $\begin{array}{c}\ln (\text { Pretax } \\
\text { Income }) \\
\end{array}$ & $\begin{array}{c}\ln (\text { Pretax } \\
\text { Income }) \\
\end{array}$ & $\ln$ (Sales) & $\ln$ (Sales) & $\ln (\mathrm{Debt})$ \\
\hline Column & $(1)$ & (2) & (3) & (4) & (5) & $(6)$ & $(7)$ & (8) \\
\hline Interpretation & $\begin{array}{l}\text { Labor } \\
\text { Prod. }\end{array}$ & ROA & $\begin{array}{l}\text { Inventory } \\
\text { Turnover }\end{array}$ & ROE & $\begin{array}{c}\text { Profit } \\
\text { Margin }\end{array}$ & $\begin{array}{c}\text { Asset } \\
\text { Utilization }\end{array}$ & $\begin{array}{l}\text { Collection } \\
\text { Efficiency }\end{array}$ & Leverage \\
\hline ERP live & $\begin{array}{l}.027 \\
(.053)\end{array}$ & $\begin{array}{l}.013 \\
(.088)\end{array}$ & $\begin{array}{c}.061 \\
(.070)\end{array}$ & $\begin{array}{l}.069 \\
(.089)\end{array}$ & $\begin{array}{l}-.005 \\
(.092)\end{array}$ & $\begin{array}{l}.103 * * \\
(.049)\end{array}$ & $\begin{array}{c}.059 \\
(.052)\end{array}$ & $\begin{array}{c}.032 \\
(.147)\end{array}$ \\
\hline L1.ERP live & $\begin{array}{l}.040 \\
(.063)\end{array}$ & $\begin{array}{l}-.043 \\
(.099)\end{array}$ & $\begin{array}{l}.072 \\
(.075)\end{array}$ & $\begin{array}{l}-.038 \\
(.097)\end{array}$ & $\begin{array}{l}-.061 \\
(.106)\end{array}$ & $\begin{array}{l}.039 \\
(.051)\end{array}$ & $\begin{array}{l}.002) \\
-.011 \\
(.061)\end{array}$ & $\begin{array}{l}.093 \\
(.163)\end{array}$ \\
\hline L2.ERP live & $\begin{array}{l}-.065 \\
(.062)\end{array}$ & $\begin{array}{l}-.157 \\
(.103)\end{array}$ & $\begin{array}{l}-.001 \\
(.070)\end{array}$ & $\begin{array}{l}-.129 \\
(.103)\end{array}$ & $\begin{array}{l}-.184^{*} \\
(.109)\end{array}$ & $\begin{array}{l}.015 \\
(.045)\end{array}$ & $\begin{array}{l}.034 \\
(.056)\end{array}$ & $\begin{array}{l}.062 \\
(.153)\end{array}$ \\
\hline L3.ERP live & $\begin{array}{l}-.031 \\
(.054)\end{array}$ & $\begin{array}{l}.109 \\
(.094)\end{array}$ & $\begin{array}{c}.045 \\
(.064)\end{array}$ & $\begin{array}{l}.106 \\
(.099)\end{array}$ & $\begin{array}{l}.095 \\
(.099)\end{array}$ & $\begin{array}{l}.039 \\
(.039)\end{array}$ & $\begin{array}{l}-.005 \\
(.048)\end{array}$ & $\begin{array}{l}.047 \\
(.138)\end{array}$ \\
\hline SCM live & $\begin{array}{c}.356 * * * \\
(.042)\end{array}$ & $\begin{array}{l}.136 * * \\
(.070)\end{array}$ & $\begin{array}{l}.110^{* *} \\
(.047)\end{array}$ & $\begin{array}{l}.208 * * \\
(.072)\end{array}$ & $\begin{array}{l}.114 \\
(.073)\end{array}$ & $\begin{array}{l}.062 * * \\
(.029)\end{array}$ & $\begin{array}{c}.182 * * * \\
(.034)\end{array}$ & $\begin{array}{l}.192 * \\
(.104)\end{array}$ \\
\hline CRM live & $\begin{array}{l}.229 * \\
(.137) \\
\end{array}$ & $\begin{array}{l}.168 \\
(.168) \\
\end{array}$ & $\begin{array}{l}.226^{*} \\
(.119) \\
\end{array}$ & $\begin{array}{c}.303 \\
(.188) \\
\end{array}$ & $\begin{array}{l}.128 \\
(.169) \\
\end{array}$ & $\begin{array}{l}.107 * * \\
(.056) \\
\end{array}$ & $\begin{array}{l}-.027 \\
(.099) \\
\end{array}$ & $\begin{array}{l}-.040 \\
(.268) \\
\end{array}$ \\
\hline $\begin{array}{l}\text { Control } \\
\text { Variables }\end{array}$ & $\begin{array}{c}\text { Industry } \\
\text { Year }\end{array}$ & $\begin{array}{c}\text { Industry } \\
\text { Year }\end{array}$ & $\begin{array}{c}\text { Industry } \\
\text { Year }\end{array}$ & $\begin{array}{c}\text { Industry } \\
\text { Year }\end{array}$ & $\begin{array}{c}\text { Industry } \\
\text { Year }\end{array}$ & $\begin{array}{c}\text { Industry } \\
\text { Year }\end{array}$ & $\begin{array}{c}\text { Industry } \\
\text { Year }\end{array}$ & $\begin{array}{c}\text { Industry } \\
\text { Year }\end{array}$ \\
\hline $\mathrm{R}^{2}$ & .88 & .76 & .82 & .75 & .74 & .90 & .91 & .58 \\
\hline Observations & 2539 & 1803 & 2180 & 1773 & 1803 & 2601 & 2574 & 2203 \\
\hline
\end{tabular}

\begin{tabular}{lcc}
\hline \multicolumn{3}{c}{ Table 9: Productivity Returns to SCM and CRM and } \\
Lagged Estimates of ERP
\end{tabular}


The delayed performance effects of ERP do not explain the performance effects of SCM and CRM; these systems have a significant positive effect on performance beyond that of the delayed effect of ERP. We find similar results in the Cobb-Douglas productivity specifications (Table 9).

\section{Explanation 3: Selection Effect}

It could also be that only firms with successful ERP implementations go on to purchase and implement SCM and CRM. If unsuccessful ERP implementers tend not to purchase and implement SCM and CRM, our SCM and CRM variables will empirically separate successful ERP implementers from unsuccessful ones and therefore contaminate our parameter estimates with the organizational characteristics of successful ERP adopters (e.g., time-invariant characteristics and organizational changes made during successful ERP implementation) and the benefits of ERP. These effects could upwardly bias estimates of SCM and CRM and downwardly bias estimates of ERP by leaving only unsuccessful ERP implementations in the sub-sample of firms that do not adopt SCM or CRM.

To evaluate this proposition, we create a variable called "ERP only" to track firms that adopted ERP but not the other suites in any year, and compare firms that only adopt ERP with those that also adopt SCM and CRM. As all firms that adopt SCM and CRM in our data have adopted ERP, this analysis in effect compares 'ERP only' firms with those that go on to adopt SCM and/or CRM (labeled "ERP plus"). If the selection effect exists in our data, ERP only firms should exhibit negative performance impacts, whereas ERP plus firms should enjoy positive performance impacts.

\begin{tabular}{|c|c|c|c|c|c|c|c|c|}
\hline \multicolumn{9}{|c|}{ Table 10: Performance Effects of ERP Only versus ERP Plus ${ }^{17}$} \\
\hline $\begin{array}{l}\text { Dependent } \\
\text { Variable }\end{array}$ & $\ln ($ Sales $)$ & $\begin{array}{c}\ln (\text { Pretax } \\
\text { Income })\end{array}$ & $\ln (\mathrm{COGS})$ & $\begin{array}{c}\ln (\text { Pretax } \\
\text { Income) }\end{array}$ & $\begin{array}{l}\text { Ln(Pretax } \\
\text { Income) }\end{array}$ & $\ln ($ Sales $)$ & $\ln ($ Sales $)$ & $\ln ($ Debt $)$ \\
\hline Column & $(1)$ & $(2)$ & (3) & $(4)$ & $(5)$ & (6) & $(7)$ & $(8)$ \\
\hline Interpretation & $\begin{array}{l}\text { Labor } \\
\text { Prod. }\end{array}$ & ROA & $\begin{array}{l}\text { Inventory } \\
\text { Turnover }\end{array}$ & ROE & $\begin{array}{c}\text { Profit } \\
\text { Margin }\end{array}$ & $\begin{array}{c}\text { Asset } \\
\text { Utilization }\end{array}$ & $\begin{array}{l}\text { Collection } \\
\text { Efficiency }\end{array}$ & Leverage \\
\hline ERP only & $\begin{array}{l}.077^{*} \\
(.032)\end{array}$ & $\begin{array}{l}-.109^{*} \\
(.050)\end{array}$ & $\begin{array}{l}.021 \\
(.043)\end{array}$ & $\begin{array}{c}.142 * * \\
(.051)\end{array}$ & $\begin{array}{l}.072 \\
(.052)\end{array}$ & $\begin{array}{c}.093^{* * *} \\
(.027)\end{array}$ & $\begin{array}{c}-.011 \\
(.029)\end{array}$ & $\begin{array}{l}.192^{*} \\
(.080)\end{array}$ \\
\hline $\begin{array}{l}\text { ERP plus } \\
\text { SCM or CRM }\end{array}$ & $\begin{array}{c}.327^{* * *} \\
(.040) \\
\end{array}$ & $\begin{array}{l}.097 \\
(.064) \\
\end{array}$ & $\begin{array}{c}.209^{* * *} \\
(.043) \\
\end{array}$ & $\begin{array}{l}.136^{*} \\
(.068) \\
\end{array}$ & $\begin{array}{l}.064 \\
(.065) \\
\end{array}$ & $\begin{array}{c}.158 * * * \\
(.028)\end{array}$ & $\begin{array}{c}.131 * * * \\
(.030)\end{array}$ & $\begin{array}{l}.198^{*} \\
(.096) \\
\end{array}$ \\
\hline Control & Industry & Industry & Industry & Industry & Industry & Industry & Industry & Industry \\
\hline Variables & Year & Year & Year & Year & Year & Year & Year & Year \\
\hline $\mathrm{R}^{2}$ & .87 & .77 & .82 & .77 & .76 & .91 & .91 & .62 \\
\hline Obs. & 4135 & 3160 & 3593 & 3095 & 3160 & 4302 & 4251 & 3669 \\
\hline
\end{tabular}

When we compare firms that only adopt ERP with those that adopt SCM or CRM too, we find a negative correlation with productivity and performance; firms that implement the full suite of enterprise systems perform significantly better across all performance dimensions.

\footnotetext{
${ }^{17}$ Dummy variables for ERP only and ERP plus are mutually exclusive by year. Variables are entered simultaneously into regressions with appropriate controls.
} 


\begin{tabular}{lc}
\hline \multicolumn{2}{c}{ Table 11: Productivity Effects of ERP Only } \\
versus ERP Plus
\end{tabular}

\section{Explanation 4: Complementarities}

Finally, there may be complementarities among ERP, SCM, and CRM systems. ERP systems provide integrated data, processes, and interfaces that enable effective execution of supply chain activities and use of customer data. Information inputs from supply chain partners can influence or automate planning of internal production activities, and production planning information can help supply chain partners optimize their distribution and logistics. Mithas et al. (2005) find that firms with greater supply chain integration are more likely to benefit from CRM applications. However, the robust measurement of complementarities requires evidence of both the covariance of complementary elements and positive effects of the co-presence of complements on performance (Milgrom \& Roberts 1990; Athey \& Stern 1998; Bresnahan et al. 2002). In our data, SCM and/or CRM adopters are a perfect subset of firms that adopt ERP; thus, traditional tests of complementarity are not possible. ${ }^{18}$ Although we cannot confirm complementarity, we cannot rule it out as a possible explanation. ${ }^{19}$

\section{Addressing Simultaneity Bias in Returns to SCM and CRM}

Our first set of estimates provides clear evidence of a unidirectional, causal relationship in which ERP influences performance. Of the four alternative explanations, two predict that performance benefits to SCM and CRM systems will be associated with their use, not their purchase, whereas the other two are compatible with positive performance effects of the purchase of SCM and CRM. Since we have evidence that the lagged benefits of ERP cannot fully explain the benefits associated with SCM and CRM (Table 8), if performance is associated with the purchase of SCM and CRM systems, we have compelling evidence for our main theoretical argument: As firms succeed with IT, they invest in and adopt more IT systems. If, however, SCM and CRM purchase events are uncorrelated with performance, but go-live events are positively correlated with performance, our main argument is not supported and we instead have evidence of a strictly unidirectional causal relationship: IT $\Rightarrow>$ performance (e.g., ERP $\Rightarrow>$ performance, $\mathrm{SCM} / \mathrm{CRM}=>$ performance). If SCM and CRM are correlated with positive performance gains at both

\footnotetext{
${ }^{18}$ All SCM and CRM variables are perfectly collinear with a term interacting them with ERP adoption.

${ }^{19}$ In the presence of strong complementarities and rational management, adoption should be perfectly collinear. If learning and re-organization enable greater benefits, adoption of different systems could be lagged.
} 
purchase and go-live, then we have evidence of a 'virtuous cycle' in which firms adopt the baseline ERP platform, enjoy direct causal performance gains, and are inspired to purchase SCM and CRM, after which SCM and CRM add value beyond that explained by the lagged effects of ERP. The Appendix provides a summary of five possible causal stories about the relationship between IT and firm performance and the evidence required to support each.

\begin{tabular}{|c|c|c|c|c|c|c|c|c|}
\hline $\begin{array}{l}\text { Dependent } \\
\text { Variable } \\
\end{array}$ & $\ln$ (Sales) & $\begin{array}{c}\ln (\text { Pretax } \\
\text { Income) }\end{array}$ & $\ln (\mathrm{COGS})$ & $\begin{array}{l}\ln (\text { Pretax } \\
\text { Income) }\end{array}$ & $\begin{array}{l}\ln (\text { Pretax } \\
\text { Income) }\end{array}$ & $\ln$ (Sales) & $\ln$ (Sales) & $\ln ($ Debt $)$ \\
\hline Column & $(1)$ & (2) & (3) & (4) & (5) & (6) & (7) & (8) \\
\hline Interpretation & $\begin{array}{l}\text { Labor } \\
\text { Prod. }\end{array}$ & ROA & $\begin{array}{l}\text { Inventory } \\
\text { Turnover }\end{array}$ & ROE & $\begin{array}{c}\text { Profit } \\
\text { Margin }\end{array}$ & $\begin{array}{c}\text { Asset } \\
\text { Utilization }\end{array}$ & $\begin{array}{l}\text { Collection } \\
\text { Efficiency }\end{array}$ & Leverage \\
\hline $\begin{array}{l}\text { SCM: } \\
\text { Purchase }\end{array}$ & $\begin{array}{c}.139 * * * \\
(.043)\end{array}$ & $\begin{array}{l}-.006 \\
(.057)\end{array}$ & $\begin{array}{c}.261 * * * \\
(.056)\end{array}$ & $\begin{array}{l}-.005 \\
(.056)\end{array}$ & $\begin{array}{c}.047 \\
(.059)\end{array}$ & $\begin{array}{c}-.091 * * \\
(.027)\end{array}$ & $\begin{array}{c}.033 \\
(.022)\end{array}$ & $\begin{array}{l}-.030 \\
(.100)\end{array}$ \\
\hline SCM: Live & $\begin{array}{c}.381 * * * \\
(.038)\end{array}$ & $\begin{array}{l}.105^{*} \\
(.061) \\
\end{array}$ & $\begin{array}{c}.241 * * * \\
(.041) \\
\end{array}$ & $\begin{array}{l}.145^{* *} \\
(.064) \\
\end{array}$ & $\begin{array}{c}.058 \\
(.062) \\
\end{array}$ & $\begin{array}{c}.118^{* * *} \\
(.026)\end{array}$ & $\begin{array}{c}.184 * * * \\
(.028)\end{array}$ & $\begin{array}{l}.199 * * \\
(.089) \\
\end{array}$ \\
\hline $\begin{array}{l}\text { Control } \\
\text { Variables }\end{array}$ & $\begin{array}{l}\text { Industry } \\
\text { Year }\end{array}$ & $\begin{array}{l}\text { Industry } \\
\text { Year }\end{array}$ & $\begin{array}{l}\text { Industry } \\
\text { Year }\end{array}$ & $\begin{array}{l}\text { Industry } \\
\text { Year }\end{array}$ & $\begin{array}{l}\text { Industry } \\
\text { Year }\end{array}$ & $\begin{array}{l}\text { Industry } \\
\text { Year }\end{array}$ & $\begin{array}{l}\text { Industry } \\
\text { Year }\end{array}$ & $\begin{array}{l}\text { Industry } \\
\text { Year }\end{array}$ \\
\hline $\mathrm{R}^{2}$ & .87 & .77 & .82 & .77 & .77 & .91 & .91 & .62 \\
\hline Observations & 4135 & 3160 & 3593 & 3095 & 3160 & 4302 & 4251 & 3669 \\
\hline
\end{tabular}

Table 13: Performance Comparisons During License Purchase and After Go-Live: CRM

\begin{tabular}{|c|c|c|c|c|c|c|c|c|}
\hline $\begin{array}{l}\text { Dependent } \\
\text { Variable }\end{array}$ & $\ln$ (Sales) & $\begin{array}{c}\ln (\text { Pretax } \\
\text { Income })\end{array}$ & $\ln (\mathrm{COGS})$ & $\begin{array}{c}\ln (\text { Pretax } \\
\text { Income })\end{array}$ & $\begin{array}{c}\ln (\text { Pretax } \\
\text { Income })\end{array}$ & $\ln$ (Sales) & $\ln$ (Sales) & $\ln ($ Debt $)$ \\
\hline Column & (1) & (2) & (3) & (4) & $(5)$ & (6) & (7) & (8) \\
\hline Interpretation & $\begin{array}{l}\text { Labor } \\
\text { Prod. }\end{array}$ & ROA & $\begin{array}{l}\text { Inventory } \\
\text { Turnover }\end{array}$ & ROE & $\begin{array}{c}\text { Profit } \\
\text { Margin }\end{array}$ & $\begin{array}{c}\text { Asset } \\
\text { Utilization }\end{array}$ & $\begin{array}{l}\text { Collection } \\
\text { Efficiency }\end{array}$ & Leverage \\
\hline $\begin{array}{l}\text { CRM: } \\
\text { Purchase }\end{array}$ & $\begin{array}{c}.162 * * * \\
(.049) \\
.354 * * \\
(.133) \\
\end{array}$ & $\begin{array}{c}-.013 \\
(.101) \\
.220 \\
(.162) \\
\end{array}$ & $\begin{array}{l}.113 * * \\
(.052) \\
.298 * * \\
(.116) \\
\end{array}$ & $\begin{array}{c}.050 \\
(.108) \\
.366^{* *} \\
(.181) \\
\end{array}$ & $\begin{array}{c}.143 \\
(.106) \\
.128 \\
(.162) \\
\end{array}$ & $\begin{array}{c}.045 \\
(.047) \\
.171^{* *} \\
(.058) \\
\end{array}$ & $\begin{array}{c}.056 \\
(.037) \\
-.032 \\
(.093) \\
\end{array}$ & $\begin{array}{l}-.225 \\
(.178) \\
-.025 \\
(.269) \\
\end{array}$ \\
\hline $\begin{array}{l}\text { Control } \\
\text { Variables }\end{array}$ & $\begin{array}{c}\text { Industry } \\
\text { Year }\end{array}$ & $\begin{array}{c}\text { Industry } \\
\text { Year }\end{array}$ & $\begin{array}{l}\text { Industry } \\
\text { Year }\end{array}$ & $\begin{array}{c}\text { Industry } \\
\text { Year }\end{array}$ & $\begin{array}{c}\text { Industry } \\
\text { Year }\end{array}$ & $\begin{array}{c}\text { Industry } \\
\text { Year }\end{array}$ & $\begin{array}{c}\text { Industry } \\
\text { Year }\end{array}$ & $\begin{array}{c}\text { Industry } \\
\text { Year }\end{array}$ \\
\hline $\mathrm{R}^{2}$ & .87 & .77 & .82 & .77 & .77 & .90 & .91 & .62 \\
\hline Observations & 4135 & 3160 & 3593 & 3095 & 3160 & 4302 & 4251 & 3669 \\
\hline
\end{tabular}

Tables 12 and 13 display results from SCM and CRM purchase and go-live analyses. The strongest positive correlations with performance emerge after go-live events, but purchase events are also positively associated with performance, casting doubt on three of the causal interpretations in the Appendix. ${ }^{20}$ The results could be consistent with either classic simultaneity or virtuous cycle explanations, but the unidirectional causal relationship between initial ERP investments and performance ultimately lends the most credibility to the virtuous cycle interpretation. A convoluted story would be needed to explain why such strong simultaneity occurs for SCM and CRM estimations but not ERP estimations, especially given our controls for temporal and industry specific shocks.

As a robustness check and to ensure our results are not artifacts of our estimation strategy, we independently estimate the impact of higher performance on the likelihood of purchasing ERP, SCM, and CRM systems using the standard logistic regression model formalized in equation 3. If simultaneity does not affect the results, we expect no

\footnotetext{
${ }^{20}$ The negative relationship between SCM and asset utilization may indicate complementarities between SCM and outsourcing. Firms may push asset ownership to suppliers as they gain control over supply chain information. This is consistent, for example, with Dell's strategy.
} 
impact (or a negative impact) of performance on the likelihood of purchasing IT. The evidence instead shows that performance predicts the purchase of later-stage SCM and CRM investments but not initial ERP investments, corroborating our other evidence (Table 14). ${ }^{21}$

\begin{tabular}{lccc}
\hline \multicolumn{4}{c}{ Table 14. Logistic Regression of the Impact of Prior Performance on the } \\
Probability of Adopting ERP, SCM, and CRM
\end{tabular}

Together, these results support the virtuous cycle interpretation and explicitly reject some part of the other interpretations. In the end, we are left with compelling, large-sample, statistical evidence of a particular causal relationship between IT and firm performance in the context of enterprise systems: a virtuous cycle of snowballing IT investments driven by rational economic decisions that compel firms to invest in high marginal return assets like IT.

\section{Conclusion}

Whether IT causes productivity and performance increases is one of the most critical questions in IT research. Only a definitive answer to this question can resolve the debate about whether IT really "pays off" or if performance increases correlated with IT investments are simply a by-product of other drivers of success. Studies of IT value have used successively more sophisticated econometric methods to disentangle causality in the IT-performance relationship with mixed results. Generally speaking, good instrumental variables are hard to find; most are too weak to provide explanatory power or not exogenous enough to address reverse causality.

By analyzing a remarkable data set that separates purchasing decisions from IT implementation and use, we approach the causality question from a new angle. Our empirical strategy highlights a new tool to tease apart casualty in the IT literature. We use this tool in the context of enterprise systems, one of the largest and most ubiquitous categories of IT investment at the enterprise level. Our results (1) clarify the causal relationships between IT and performance; (2) provide up-to-date estimates of the impact of enterprise systems; and (3) provide new evidence of the differential returns to internal and external IT adoption. Furthermore, we identify several new issues in the estimation of returns to systems of process-enabling IT.

\footnotetext{
${ }^{21}$ Results remain substantially unchanged when analyzing effects of lagged measures of performance $(t-1 ; t-2)$ on the
} probability of adopting ERP, SCM and CRM. 
Most importantly, our results reveal a new perspective with which to view causality in IT value research. We find evidence that ERP causes performance increases rather than performance inspiring ERP purchases. We then demonstrate that success with ERP encourages adoption of extended enterprise systems, which in turn improve productivity and operational performance. Our results support the view that a "virtuous cycle" exists in the relationship between IT investment and performance, such that initial investments drive performance gains, which encourage further investments, over the course of several years. Our data contradict most alternative views of causality in the IT literature, and our perspective fits with rational economic theory - predicting investments in assets with the highest marginal return. With this work, we hope to open a new direction of inquiry into IT value.

\section{Acknowledgements}

We are grateful to the National Science Foundation (IIS-0085725), the Marvin Bower Fellowship, and the MIT Center for Digital Business for generous funding. We thank Lorin Hitt, Elisabeth Caswell and participants at the Workshop on Information Systems and Economics for valuable comments. 


\section{References}

Andersen, E.W., and Sullivan, M.W. "The Antecedents and Consequences of Customer Satisfaction for Firms," Marketing Science (12:2), 1993, pp. 125-143.

Arellano, M., and Bond, S.R. 1991. "Some Tests of Specification for Panel Data: Monte Carlo Evidence and an Application to Employment Equations," Review of Economic Studies (58:2), 1991, pp. 277-297.

Athey, S., and Stern, S. "An Empirical Framework for Testing Theories about Complementarity in Organizational Design," NBER Working Papers 6600, 1998.

Barua, A., Kriebel, C. H., and Mukhopadhyay, T. "Information Technologies and Business Value: An Analytic and Empirical Investigation," Information Systems Research (6:1), 1995, pp. 3-23.

Bharadwaj, A. S., Bharadwaj, S. G., and Konsynski, B. R. "Information Technology Effects on Firm Performance as Measured by Tobin's q," Management Science (45:7), 1999, pp. 1008-1024.

Bresnahan, T., Brynjolfsson, E., and Hitt, L. M. "Information Technology, Workplace Organization and the Demand for Skilled Labor: Firm-level Evidence," Quarterly Journal of Economics (117:1), 2002, pp. 339-376.

Brynjolfsson, E., and Hitt, L.M. "Paradox Lost? Firm-level Evidence on the Returns to Information Systems Spending," Management Science (42:4), 1996, pp. 541-558.

Brynjolfsson, E., and Hitt, L.M. "Beyond Computation: Information Technology, Organizational Transformation and Business Performance," Journal of Economic Perspectives (14:4), 2000, pp. 23-48.

Brynjolfsson, E., and Hitt, L.M. "Computing Productivity: Firm-Level Evidence," Review of Economics and Statistics (85:4), 2003, pp. 793-808.

Cachon, G. P., and Fisher, M. "Supply Chain Inventory Management and the Value of Shared Information," Management Science (46:8), 2000, pp. 1032-1048.

Clemons E. K., Reddi, S. P., and Row, M. "The Impact of Information Technology on the Organization of Economic Activity: The Move to the Middle Hypothesis," Journal of Management Information Systems (10:2), 1993, pp. 9-35.

Coase, R.H. "The Nature of the Firm," Economica N.S. (4:16), 1937, pp. 386-405.

Cohen, M.A., Agrawal N., and Agrawal V. "Winning in the Aftermarket," Harvard Business Review (May), 2006, pp. 129-138.

Devaraj, S., and Kohli, R. "Performance Impacts of Information Technology: Is Actual Use the Missing Link?" Management Science (49:3), 2003, pp. 273-289.

Fisher, M.L. "What is the Right Supply Chain for Your Product?" Harvard Business Review (March-April), 1997, pp. 105-116.

Gao, G., and Hitt, L.M. "IT and Product Variety: Evidence from Panel Data," in Proceedings of the 25th Annual International Conference on Information Systems, Agaral, R. and Kirsch, L. (Eds.), Washington, D.C., December 2004: Association for Information Systems.

Griliches, Z., and Mairesse, J. "Production Functions: The Search for Identification," NBER Working Papers 5067, National Bureau of Economic Research, Inc., 1995.

Hendricks, K.B., and Singhal, V. R. "Association between Supply Chain Glitches and Operating Performance," Management Science (51:5), 2005, pp. 695-711.

Hendricks, K. B., Singhal, V. R., and Stratman, J. K. "The Impact of Enterprise Systems on Corporate Performance: A Study of ERP, SCM, and CRM System Implementations," Journal of Operations Management, forthcoming.

Hitt, L.M., Wu, D. J., and Zhou, X. "Investment in Enterprise Resource Planning: Business Impact and Productivity Measures," Journal of Management Information Systems (19:1), 2002, pp. 71-98.

Hogan, J. E., Lemon, K. N., and Rust, R.T. "Customer Equity Management: Charting New Directions for the Future of Marketing," Journal of Service Research (5:1), 2002, pp. 4-12.

Holmstrom, B., and Roberts, J. "The Boundaries of the Firm Revisited," Journal of Economic Perspectives (12), 1998, pp. 73-94.

Ichniowski, C., Shaw, K., and Prennushi, G. "The Effects of Human Resource Management Practices on Productivity: A Study of Steel Finishing Lines," American Economic Review (87:3), 1997, pp. 291-313.

Jensen M. C., and Meckling, W. H. "Theory of the Firm: Managerial Behavior, Agency Costs, and Ownership Structure," Journal of Financial Economics 3, 1976, pp. 295-316.

Lee, H., V. Padmanabhan, S. Whang. "Information Distortion in a Supply Chain: The Bullwhip Effect," Management Science (43:4), 1997, pp. 546-558.

Markus, L.M, Tanis, C., and van Fenema, P.C. "Multisite ERP Implementations," Communications of the ACM (43:4), 2000, pp. 42-46. 
McAfee, A. "The Impact of Enterprise Technology Adoption on Operational Performance: An Empirical Investigation," Production and Operations Management Journal (11:1), 2002, pp. 33-53.

McAfee, A. "When Too Much IT Knowledge is a Dangerous Thing," MIT Sloan Management Review (44:2), 2003, pp. 83-89.

Melville, N., Kraemer, K., and Gurbaxani, V. "Review: Information Technology and Organizational Performance: An Integrative Model of IT Business Value," MIS Quarterly (28:2), 2005, pp. 283-322.

Milgrom, P., and Roberts, J. "The Economics of Modern Manufacturing: Technology, Strategy and Organization," American Economic Review (80:3), 1990, pp. 511-528.

Mithas, S., and Krishnan, M.S. "Causal Effect of CRM Systems on Cross Selling Effectiveness and Sales-force Productivity by Bounding a Matching Estimator," in Proceedings of the Ninth Annual INFORMS Conference on Information Systems and Technology, Bhargava, H., C. Forman, R. Kauffman, D.J. Wu (Eds.), Denver, CO, 2004.

Mithas, S., Krishnan, M. S. and Fornell, C. "Why Do Customer Relationship Management Applications Affect Customer Satisfaction?" Journal of Marketing 69, 2005, pp. 201-209.

Mukhopadhyay, T., Rajiv, S., and Srinivasan, K. "Information Technology Impact on Process Output and Quality," Management Science (43:12), 1997, pp. 1645-1659.

O’Leary, D. Enterprise Resource Planning Systems: Life Cycle, Electronic Commerce, and Risk. Cambridge University Press, New York, 2000.

Olley, S., and Pakes, A. "The Dynamics of Productivity in the Telecommunications Equipment Industry," Econometrica (64:6), 1996, pp. 1263-1298.

Swanson, E.B., and Wang, P. "Knowing Why and How to Innovate with Packaged Business Software," Working Paper, The Anderson School at UCLA, Los Angeles, CA, 2003. 


\begin{tabular}{|c|c|c|c|c|}
\hline \multicolumn{5}{|c|}{ Appendix. Causal Interpretations of the Relationship Between IT and Firm Performance: The Cases of ERP, SCM \& CRM } \\
\hline Theory & Required Evidence & Relationship Paths & $\begin{array}{l}\text { Supported } \\
\text { for ERP? }\end{array}$ & $\begin{array}{c}\text { Supported for } \\
\text { SCM/CRM? }\end{array}$ \\
\hline $\begin{array}{l}\text { Performance- } \\
\text { Led IT } \\
\text { Investment }\end{array}$ & $\begin{array}{l}\text { No relationship between go-live of } \\
\text { enterprise systems and performance }\end{array}$ & & NO & NO \\
\hline $\begin{array}{l}\text { IT-Driven } \\
\text { Performance }\end{array}$ & $\begin{array}{l}\text { - No relationship between performance and } \\
\text { purchase of enterprise systems } \\
\text { - Positive relationship between } \\
\text { performance and go-live of enterprise } \\
\text { systems }\end{array}$ & & YES & NO \\
\hline Virtuous Cycle & $\begin{array}{l}\text { - No relationship between performance and } \\
\text { purchase of ERP } \\
\text { - Positive relationship between go-live of } \\
\text { ERP and performance } \\
\text { - } \begin{array}{l}\text { Positive relationship between } \\
\text { performance and purchase of SCM/CRM }\end{array} \\
\text { - } \begin{array}{l}\text { Positive relationship between go-live of } \\
\text { SCM/CRM and performance (beyond } \\
\text { performance gains from ERP) }\end{array}\end{array}$ & & YES & YES \\
\hline
\end{tabular}

